\title{
The impact of translation on L2 learners' metalinguistic competence
}

Parinaz, Khayatan $\bowtie$

Islamic Azad University, Isfahan (Khorasgan) Branch, Iran (Parinaz_khayatan@yahoo.com)

Biria, Reza

Islamic Azad University, Isfahan (Khorasgan) Branch, Iran (biria_reza@yahoo.com)

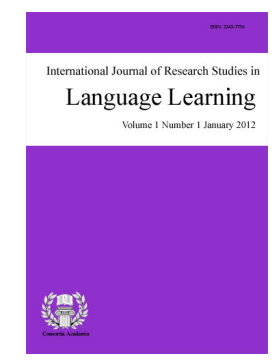

ISSN: $2243-7754$ Online ISSN: 2243-7762

OPEN ACCESS

\section{Abstract}

This paper investigates the effect of translation courses and language proficiency on learners' metalinguistic knowledge at Isfahan University, Iran. Tests of Metalinguistic knowledge, language proficiency and a background questionnaire were administered to learners of translation fields of study (as the experimental group) and the control group of English literature learners at Isfahan University, Iran. Each of translation and literature groups were further ranked into 4 groups by their language proficiency. It was found that learners' metalinguistic ability and their language proficiency are not correlated. Multivariate analyses indicated that both groups did not show any awareness of certain properties of language as MLK. However, it was shown that Translation learners were better at language analytic section of the metalinguistic test. It is suggested that translation courses can increase the learners' language analytic ability. The importance and the theoretical implications of the results are also counted for language teaching and testing.

Keywords: metalinguistic knowledge; translation strategy; explicit knowledge 


\section{The impact of translation on L2 learners' metalinguistic competence}

\section{Introduction}

From the time the first social structures appeared and human beings started to communicate both socially and emotionally with members of their own species from other societies, they realized that there was a strong need for an intermediary to aid the interactions, without which such strives, would be like "talking to a brick wall." This is how translation, as one of the earliest tools in international communications, came up. Since then, there has always been a dispute over the issue of translation. However, In addition to this common perception as a device for transferring meanings and conveying messages, translation can also be viewed as a strategy for learning second languages (L2).

Although many L2 educators have overlooked the place of translation in language teaching, translation is extensively applied in learners' learning process (Chamot et al., 1987; Naiman et al., 1978; O'Malley et al., 1985b; Politzer, 1983; Viano \& Orquin, 1982). Oxford (1990) believes that the features and approaches of language learning and translation process are alike. In addition, Naiman et al. (1978, p. 14) learnt that one of the strategies employed by good L2 learners was to "refer back to their native languages (NL) judiciously (translating to their L1) and make effective cross-lingual comparisons at different stages of language learning". Therefore, he concluded that L2 learners frequently employ translation as a learning strategy to comprehend, remember, and produce an L2. Therefore, translating shouldn't merely be considered as mechanical transfer of text proposition from one language to another, rather, it can also aid L2 learners to enhance and facilitate the acquisition of linguistic competence. Thus, translator is not solely a laborer as is normally understood, but s/he is a person with linguistic competence.

On the other hand, since the interplay between translation and metalinguistic knowledge (MLK) is going to be investigated in the paper, let's take a look at the other side of the coin. The centerpiece of any language is its grammatical rules and they cannot be neglected. In most of the times, L2 learners are often subjected to explicit teaching and learning of an L2 features that require a systematic description. In general terms, explicit knowledge is declarative knowledge that can be brought into awareness and that is potentially available for verbal report (Anderson, 2005; Hulstijn, 2005). While, implicit knowledge is knowledge that cannot be brought into awareness or articulated. As one of the subcategories of explicit knowledge, metalinguistic knowledge is interpreted as L2 learners' explicit knowledge about an L2 (Alderson et al., 1997; Bialystok, 1979; Elder et al., 1999). MLK seems to be composed of information or capacities which cannot be linked directly to the communicative use of language (Dakowska, 1997). And it is in contrary to the present tendency in the theory and practice of foreign language teaching (FLT) which mostly cares for communicative ability in the target language (TL), and emphasizes more on sociolinguistic approaches to the curriculum development than to the mastery of grammatical structures or a formal knowledge of the grammar of the language (Alderson, Clapham, \& Steel, 1997). However, it should be kept in the mind that unfortunately, the underlying assumption of most learning and teaching atmosphere is that learners have an explicit knowledge about language, use metalinguistic terminology or draw on explicit knowledge in their language and presuppose a certain familiarity with the concepts on the part of students (Bloor, 1995) and it appears to cause a problem for the FLT (Bloor, 1986).

To begin, a review on the related literature and major contributions both from a theoretical perspective and empirical evidence is conducted. Then based on the gaps of the studies, the author deals with the statement of the problem and purpose of the paper, and then the empirical session is presented. The conclusions of the article aim to make foreign language (FL) educators sensitive to the practical benefits of using translation for learning. The importance and the theoretical implications of the results are also counted for language teaching and testing. 


\section{Literature Review}

Using translation as a teaching technique has had many ups and downs, that is, in different periods it has been accepted as a teaching device or regarded as a controversial subject depending on prevailing objectives and teaching preferences (Rivers \& Temperely, 1978). Since years ago, translation was precisely as the focal point of language teaching and it was also considered as a fundamental component in medieval universities and schools (Bonyadi, 2003; Duff, 1990).

In terms of using translation as a learning strategy, it has been categorized as the cognitive learning strategy (Chamot, 1987; Chamot et al., 1987; Chamot \& Kupper, 1989; O'Malley et al., 1985a; Oxford, 1990). In fact, as Goff-Kfouri points out (2005), the cognitive approach discerns that learning entails the recall of facts, memory, reasoning, critical thinking, and problem solving, all of which are material to the daily activities of a translator or interpreter. Nevertheless, on the basis of CLT approach, language teachers assume that translating is not a good learning scheme (Liao, 2006). They assert that learners maximize their chances of fluency and accuracy in an L2 and avoid interference from their L1 by thinking in the TL. Nonetheless, such an assumption appears to have a lack of empirical support (Liao, 2006). For example, Corder (1981) underestimates the act of L1 translating as an invaluable resource to compensate L2 learners' weaknesses during learning an L2. He proposed to reframe the concept of 'interference' as 'intercession' in order to consider learners' use of their L1 as a strategy of communication. In fact, more and more studies have indicated positive and useful roles of translation in language learning (Aktinson, 1987; Baynham, 1983; Brooks-Carson \& Cohen, 2001; Ellis, 1985; Husain, 1994 , 1995; Kern, 1994; Kobayashi \& Rinnert, 1992; Newmark, 1991; Omura, 1996; Perkins, 1985; Prince, 1996; Tiford, 1985). In the study conducted by O'Malley et al. (1985b), translation was shown to be one of the most frequent learning strategies employed by learners. Bell (1991) also claimed that participants during translation made use of all of the direct and indirect strategies to realize the synthesis and analysis of syntactic, semantic, and pragmatic aspects of a text.

On the other hand, in the mid 1980's and early 1990's, MLK was extensively employed as a construct in research (Mora, 2001). In fact, such studies are related to the knowledge about language movement in the UK which asserts that L2 learners need to know about language to be able to learn it more quickly and to employ it more proficiently (Richmond, 1990). Current empirical research in this part consists of studies with both cross-sectional designs (e.g., Alderson et al., 1997; Elder et al., 1999; Elder \& Manwaring, 2004; Green \& Hecht, 1992; Renou, 2000; Sorace, 1985) and longitudinal ones (e.g., Klapper \& Rees, 2003).

The basic focus of some of the studies has been on the impact of MLK on proficiency (Alderson et al., 1997; Elder et al., 1999; Elder \& Manwaring, 2004; Green \& Hecht, 1992; Klapper \& Rees, 2003; Renou, 2000; Sorace, 1985). Interestingly, the results obtained are counteractive. While it has been showed in some of the studies (Alderson et al., 1997; Seliger, 1979) that there was no findings to stand up for the teaching of MLK as a means of improving L2 learners' linguistic proficiency, other studies showed that metalinguistic awareness behaves as an aid in language learning (Hulstijn \& Hulstijn, 1984). For example, Seliger (1979) didn't identify any relationship between L2 learners' ability in explaining the rule for "a and an" distinctions and their capability in employing it in their performance. Similarly, Alderson et al. (1997) concluded that MLK and language proficiency appear to make up two distinct factors of linguistic ability and aren't related to each other as much. Therefore, no justification existed to account for the argument that MLK is required for success in language learning.

On the contrary, Ruan (2004) revealed that more successful readers and writers are learners with experienced in metacognitive abilities (Baker, 2002; Raphael, Englert \& Kirschner, 1989); Besides, the findings drawn from research results confirm the fact that proficient bi-lingual and bi-literate adults and children show increased metalinguistic awareness and knowledge that enriches their capability to use linguistic processes and analysis in L2 reading (Albert \& Obler, 1978; August \& Shanahan, 2007; Bialystok, 1991, 2007; Cummins, 1976; Gass \& Selinker, 1983; Gonzez, 1999, Goswami, 1999; Muiz-Swicegood, 1994; Zunkernick, 1996); Furthermore, 
metalinguistic ability corresponds well with scores on the writing tests (including organizational ability and syntactic accuracy) (Alderson, 1997). As declared by Mora (2001), metalinguistic awareness has documented relationship and positive effects on language ability and symbolic development.

There are several explanations for the various levels of correlational strength in these studies. Different L2 proficiency levels of participants (Butler, 2002; Roehr, 2005), the type and length of previous language study (Alderson et al., 1997; Elder et al., 1999), and individual differences in cognitive or learning style (Collentine, 2000), and the tests employed to measure L2 proficiency and MLK, that is, the operationalization of the constructs under investigation may have had an impact. And still a fuller picture is going to emerge. Although tremendous amounts of researches have looked at the positive promises of using translation in language teaching and learning (Aktinson, 1987; Baynham, 1983; Brooks-Carson \& Cohen, 2001; Ellis, 1985; Husain, 1994, 1995; Kern, 1994; Kobayashi \& Rinnert, 1992; Newmark, 1991; Omura, 1996; Perkins, 1985; Prince, 1996; Tiford, 1985) very little interest has been given specifically to the effect of translation on MLK. The explanation of the impact of translation on MLK requires a more precise definition of each of which.

\subsection{Definition of Terms}

Translation is defined here, based on Robinson (1997, p.51), as 'complex processes of conscious and unconscious learning.' The paper looks at translation as a language learning technique (Kaur, 2005); and as such it has a pedagogic function, considering that its purpose is to teach a language. During translation, L2 learners must continuously jump into and back from both languages to translate all dimensions of a text. As Petrocchi (2003, p. 1) says, 'the translated piece must 'stand on its own.' and because the new text has a distinct identity, it must obey the principles of the given language (Petrocchi, 2003). Therefore, translating is somehow like re-writing and it is able to aid to learn and practice target language rules.

Metalinguistic knowledge has been operationalized as learners' capability to correct, describe, and explain L2 errors (Green \& Hetch, 1992; Renou, 2000; Sorace, 1985). However, recently, this operationalization has been stretched to include learners' language-analytic ability (Roehr, 2007) which is measured by some parts of language learning aptitude tests. Skehan $(1986,1989)$ drawing on the empirical studies conducted on Carroll's four-component model of language learning aptitude arrived to the proposal that the components of inductive language learning ability and grammatical sensitivity be assumed under a single title, that is, language-analytic ability. In some studies (Dörnyei \& Skehan, 2003; Erlam, 2005; Ranta, 2002) the concept of language-analytic ability has been picked as the learners' ability to recognize and guess the linguistic patterns. The paper concurs with both interpretations and incorporated language-analytic ability into a measure of MLK. Besides, drawing on $\mathrm{Hu}$ (2002) and R. Ellis (2004), the construct of L2 MLK is defined here as an L2 learner's explicit knowledge about the metalinguistic terminology. Moreover, MLK can exhibit itself in grammatical judgments (Clark, 1978). Grammatical judgment is defined here as the competence to judge the grammaticality of sentences or to explain or correct grammatical errors and the ability to reflect on and manipulate grammatical structures (Lazo et al., 1997). In general, as Sinclair (1986) claims the MLK measures employed here focuses on the information which converts language to the target of reflection.

\subsection{Statement of the Problem}

Let's based on the definitions provided discuss the ways that translation may affect MLK. MLK has been defined based on two components of language processing (Bialystok \& Ryan, 1985). One of them is the analysis of knowledge, the ability to shape explicit pictures of linguistic knowledge, and the other is control of processes, the capacity to control linguistic mechanisms by deliberately selecting and applying knowledge to obtain a solution. Biyalystok (1978) believes that the development of each is dependent on different experiences (Bialystok, 1987). The paper hypothesizes that one of these experiences learners encounter is translation. By translating: making blueprint, organizing, material analysis thorough reading and comprehending the content, reasoning and analyzing, translating to $\mathrm{L} 2$ texts sentence by sentence, editing, revising, rewriting, reviewing, and 
The impact of translation on L2 learners' metalinguistic competence

assessing ultimate translated text come about (Kaur, 2005). Generally, it seems as if translators have to undertake the analysis and reflection mechanisms during the translation (Kaur, 2005). Translation as the view of SLA suggests like composing might function broadly as a psycholinguistic output condition wherein learners analyze and consolidate L2 knowledge that they have previously (but not yet fully) acquired (Bialystok, 1982; Ellis, 1986; Gass, 1988; Krashen, 1984, Swain, 1985, 1988). These psycholinguistic processes in translation are also applicable to MLK in which learners consciously access the internalized grammar. The metalinguistic skills examined in this article, according to Dakowska (1993), were the abilities of verbalization of language rules, correct errors, word terminology, and grammaticality judgments. The learners' capability to make grammaticality judgments is particularly interesting because it looks to develop after learners have internalized grammatical information implicitly.

In fact, L2 learners need L2 input for learning, clearly, in any L2 classroom, the main inputs are: materials, other learners, and the teacher (Andrew, 1999). One of the input materials can be the act of translation that furnishes L2 learners with a great deal of knowledge about linguistic features. Translation can also act as an output in L2 learning because, during translation, a deep knowledge about the L1 and the L2 grammars is required to decode and encode the ideas (Kaur, 2005). Generally, output can serve a consciousness-raising function by helping L2 learners to pay attention to the problems in their interlanguage. Through consciousness-raising activities, L2 learners become aware of L2 features, encouraged to think about the L2, and to concentrate on how the L2 works (Willis \& Willis, 1996). These features are evident in MLK too and also in translation process by which the task of interpreting a source text and transferring its sense to a different linguistic system cannot be successfully done without reference to knowledge structure (Wills, 1996). For example, one method of translation is back-translation which involves the syntactical structure than the lexical level; it is based on the comparison between the patterns of the two languages in which individual lexical units may or may not match (Petrocchi, 2003). That is, the learner may focus on the surface form of a sentence while internalizing its (covert, non-observable) underlying structure (Paradis, 2006). As declared by Paradis (2006) what is available for noting isn't of a similar type than what is internalized. Regarding these considerations, learners` usually unconscious translation can be altered to a level of conscious perception. Therefore, the paper is going to investigate the relationship between translation, developing metalinguistic competence, and their role on training competent bilingual students.

The general hypothesis, then, is that translators and translation learners should have more advantage in solving metalinguistic problems in comparison to those without translation skills and learners of other field of English studies. The main focus of this research would be on whether metalinguistic competence is developed through translation procedures. The paper reports empirical evidence relating to the questions addressed by drawing on the data gathered from the various tests used. Tests of MLK, language proficiency and a background questionnaire were administered to learners of translation fields of study (as the experimental group) and the control group of English literature learners at Isfahan University, Iran. Each of translation and literature groups were further ranked into 4 groups by their language proficiency measured through a proficiency test, a narrow definition of L2 proficiency (writing proficiency) is assumed. It was found that learners' proficiency do not have any effect on their MLK test. And also, multivariate analyses indicated that at both majors the learners did not show any awareness of certain properties of language as MLK. However, it was shown that translation learners were better at language analytic section of metalinguistic test. It is suggested that translation courses can increase the learners' language-analytic ability and enhance the analytic orientation to linguistic input.

\subsection{Significance of Study}

Generally, there are some good reasons for the purposeful inclusion of translation activities in our L2 classrooms. First, because translation is a conscious process of learning, it thoroughly involves L2 learners in the learning process (Nunnan, 1999). Second, by the analysis of deep structure of linguistic forms, we can gain a more profound understanding of the syntax of languages (Chellapan, 1982). Finally, although by attending in translation sessions, they may not intend to enter the translation profession, translating itself helps them relate L1 
to L2, and they realize that it is not only a job, but something that involves their lives, their everyday experience, and that it is not a mechanical action (Petrocchi, 2003), rather, it is something that makes a difference on their learning. However, how to implement it and accommodate it in the syllabus and examination system remains to be discussed later on. On the other hand, greater degrees of explicit knowledge are associated with higher accuracy in language use. If explicit knowledge leads to automatized fluent use, then it ought to be associated with faster and higher comprehension. Then, it can provide a good piece of information for improving L2 teaching and learning techniques. Besides, because MLK of surface forms (as heard or read before) can inspire practice models and act as a monitor for checking the accuracy and appropriateness of the automatic output of the implicit system (Krashen, 1997), it can result in more correct forms. Thus, "practice under the guidance of explicit knowledge" (N. Ellis, 1994, p. 4) can help acquisition of implicit competence and have implications for current models of linguistic competence (Lazo et al., 1997) and theories about how it is acquired, developed, improved, and implemented (Pargment, 2007). Hopefully, the results of the study would be beneficial for language teachers to better admit the role of translation in language teaching and learning (Liao, 2006).

\subsection{Research Questions}

$>\quad$ What is the effect of L2 language proficiency on metalinguistic knowledge?

$>\quad$ What is the role of translation as a technique for enhancing L2 learners' metalinguistic competence?

$>\quad$ Are there any differences between metalinguistic knowledge of literature students and translation students?

\section{Methodology}

\subsection{Participants}

The initial pool of the population, for quantitative survey, consisted of 400 L1 Persian speakers enrolled as full-time undergraduate L2 learners of English at Isfahan University, Iran. The setting of the study demanded the researcher to recruit those ones who had achieved the required score in the proficiency test. So, the researcher devised a proficiency test and administered the battery to freshmen, sophomores, juniors, and seniors of literature and translation fields (these academic years of study indicate the increase of participants competence in their field of study) at Isfahan University, Iran. The freshmen in both fields who obtained the mean of around M= 23 out of 100 in English proficiency examination were selected. All chosen sophomores in both fields had obtained the mean of $\mathrm{M}=43$ in English in the proficiency examination and the score mean of the juniors in both field was $M=67$. The seniors in both fields were selected based on their $M=90$ mean score in English proficiency test. Then, the English proficiency level of the participants was slightly ranked, ranging from false beginners-freshmen- to advanced L2 learners-seniors- exhibiting good levels of linguistic competence. Ultimately, the number of participants reduced to 240 learners (160 female and 80 male learners, aged 18-22 years old).

A total of 120 participants were in undergraduate translation study-30 in each of the 4 groups (freshmen, sophomores, seniors, juniors). The remaining 120 participants were in their literature study. Thirty in each group (although pupils in the Literature English Department were taught translation as a part of their subjects, their knowledge in this regard was negligible). Having been admitted to the university, some of the participants were taking prerequisite English courses at the time of their acceptance, while others were directly enrolled in undergraduate university courses. All the participants were subject to the L2 instruction regularly. Their classes have been field-oriented, that is, the main focus has been on translating wide variety texts and documents for translation learners and English literature for control group and also included courses of conversation, reading comprehension, and grammar practice with a focus-on-forms orientation to improve the general proficiency of learners. In both groups, all the subjects were taught through English. 
To be sure that the differences between the participants were not due to unintended variables in their background, extra data were collected and checked through background questioner. Except for the intended differences in the fields of study, there were hardly any differences in their background data. One hundred and twenty of the participants from the control groups of English Literature were matched on sex and age with 120 participants from English Translation groups. They were representative samples of population since they belong to the same age group and had similar sociological, cultural, linguistic background, and learning and educational experiences. In short, the subjects were the symbols of linguistically and culturally homogeneous groups of upper intermediate-level learners found in an academic setting. As the L2 learners studied the L2 in an academic setting, the sample was representative of a specific subpopulation of L2 learners rather than a general population of L2 learners.

All the participants agreed to complete the tests and signed an ethics consent form. Besides, the L2 learners in both groups were free to pull out of the study and some did so.

\subsection{Materials}

Background Questionnaire - The background questionnaire, contained questions about the L2 learners' L1, the age they started English, the number of years in an English speaking country, other languages they had studied, whether they do translation as a profession or not, and the kind of instruction in English they had received previously.

English Proficiency Test - L2 proficiency was narrowly operationalized, as the L2 learners' knowledge of L2 grammar and vocabulary (written proficiency), that is, a subcomponent of general language ability (Bachman \& Palmer, 1996). The reason for this approach was that a more focused definition of L2 proficiency which merely concentrates on L2 structures and lexis might result in a stronger relationship with MLK (Roehr, 2007). The L2 learners' L2 proficiency was assessed by means of a 100-item TOEFL test. The L2 learners were asked to respond to 25 multiple-choice items and 50 grammatical judgment and 25 vocabulary items. 50 scores were assigned for the correct judgments for the grammatical judgment section, 25 score for multiple choice part, and 25 for vocabulary evaluation part. The participants were assigned a score of 1 each time they answered a question correctly. The Mean and the standard deviation of participants' scores were calculated.

Metalinguistic Test - The operationalization of the MLK has been different among studies (Roehr, 2007). In some studies (Green \& Hetch, 1992; Renou, 2000; Sorace, 1985), MLK has been defined as L2 learners' ability to correct, describe, and explain L2 errors. Drawing on these studies, the first section of the metalinguistic test was aimed at measuring the L2 learners' ability to correct, describe, and explain selected L2 features. In this section, each sentence had a grammatical error and the L2 learners were asked to correct the error, express the rule being broken, and provide the exact metalinguistic terminology. This section consisted of eleven L2 sentences (items 1-11). The rational for providing explanation was to make it clear whether they based their judgment on how their sentence sounds, or if they knew the rule that could help them decide. And, say what the rule was. Each of the 11 items was scored separately for correction and explanation because some participants might present a correct correction but wrong justification, while some others may give an incorrect response but right justification. The L2 learners were given one point if they corrected the error; one point if they used metalanuage correctly, and one point was given for a correct statement of the rule. Therefore, this test section yielded a maximum of 33 points. The L2 learners rule explanations were open to subjective interpretation and were, therefore, scored by other rater with an average inter-rater reliability of $81 \%$.

In some other studies, metalinguistic ability has been defined as learners' ability to term metalinguistic terminology (Alderson et al., 1997; Elder et al., 1999; Elder \& Manwaring, 2004). Accordingly, the second section presented test takers with 11 sentences and asked them to underline a structure in sentences. The given structures representing a metalinguistic terminology were presented in parenthesis in front of each sentence. One point was given for recognition of each construction in each sentence. 
In the third part, the L2 learners were presented with 10 ungrammatical sentences. The best explanation of the error of each sentence was presented to the L2 learners in multiple choice formats. The L2 learners were expected to select the rule that best accounts for each error out of the 4 choices given. Each correct response was given 1 point. The sentences in this part of the test was exactly the same as those in explanation part since it was hypothesized less proficient learners might have some difficulty in L2 production although they were aware of the grammatical rules required. In fact, the L2 learners cannot be said to lack explicit knowledge simply because they do not have the competence to articulate it (Macora \& Masterman, 2006).

More recently, MLK definition has been broadened and incorporates learners' language-analytic ability (Roehr, 2007). Skehan $(1986,1989)$ following the empirical studies undertaken in the 1980s, incorporated both the grammatical sensitivity and inductive language learning ability under a single title, that is, language-analytic ability (Roehr, 2007). As Roehr (2007) defines, the capability to identify how words function grammatically in sentences is called grammatical sensitivity (deBot et al., 2005; Dörnyei, 2005; Nagata, Aline, Ellis, \& 1999) and on the other hand, the ability to infer grammatical rules from language examples is inductive language learning ability. As cited in Roehr (2007, p. 162) 'language-analytic ability and metalinguistic skill can be viewed as two sides of the same coin'. The language-analytic section of the metalanguage test consisted of 8 paragraphs in which a key sentence representing a specific structure is underlined. In the following parts of paragraph, some other sentences and structures are underlined, too. The paragraphs demands the participants to choose the option which they think played the same grammatical function as the underlined structure in the key sentence. This part is simulated from the subtest of MLAT called words-in-sentences; since a sentence was represented to participants with one specific structure being highlighted, there was no need for metalinguistic terminology or labeling. In a multiple-choice format, they were, then, required to recognize in the following sentences the appropriate structure playing an analogous grammatical role. Actually, this task type was utilized to shed light on L2 pragmatic and discursive context competence, in other words, these items could not be considered and explained with the justifications of an isolated sentence (Roehr, 2007). One point is given for each correct response.

Thus, the maximum number of points that could be achieved was 62 (11 for correction, 11 for description, 11 for metalinguistic terminology, 10 for underlying the required construct, 10 for the multiple choice part, and 8 for language analysis). First, the mean, standard deviation, and variance of each participant's level of proficiency on this test were calculated to be used for answering the first research question. Second, these scores were compared by between group comparison to answer the second and third research questions. Multivariate analysis of MANOVA was used for the analysis of the data. It is noteworthy to mention that whether such test really measure explicit knowledge (as opposed to implicit knowledge) is now considered to be dependent of a number of conditions of which the pressure to respond within a given time, and the use of 'rule' rather than 'feel' are the most important (Macora \& Masterman, 2006).

The metalinguistic test was prepared by the researcher as no standardized test of this type at this level was available. This test was checked for accuracy, relevance, and consistency. The metalanguage test had been pretested, amended, and piloted. This test was piloted with L2 learners studying English in Khorasgan University whose knowledge could be considered close to that of the sample. The final number of items was decreased by item trimming and hence the maximum number of points that could be achieved was 62 . The revised version as used in the current article resulted in somewhat mixed reliability indices ( $\alpha=0.840$ for Multiple Choices; $\alpha=$ 0.832 for Underline Part; $\alpha=0.818$ for correction/description/ explanation; $\alpha=0.624$ for language analysis). The relatively low reliability of the language-analytic section has to be kept in mind during the interpretation of the results. However, because of the small number of items in this section, decreased reliability was expected. The application of Cronbach reliability co-efficient to the final form of the instrument showed a high level of internal consistency across the four parts $(\alpha=0.82)$.

The criterion for choosing the linguistic structures used in the study is that they were representative of the full range of structures covered in a typical teaching syllabus and were drawn from all levels of this syllabus. 
The impact of translation on L2 learners' metalinguistic competence

Hence, targeted features were based on notions of pedagogical grammar (McDonough, 2002; Swan, 1994; Westney, 1994) rather than a specific linguistic theory. The language test items concentrated on six categories: active/passive progressive participles, appositive phrases, parallel structures, dangling constructions, and coordination.

\subsection{Procedure}

The design of the study featured 2 phases arranged to occur within a one-month period in a raw. In the first phase, a pilot study was undertaken to specify the suitability and predictive validity of the measures which would be practiced in the main study. In the second phase, the tests were administered in 2 separate sessions, with the proficiency test and background questionnaire preceding the metalanguage test by one week. Within the second session a number of training examples for the participants to practice on were included. Written instructions on the test were given to the subjects. The subjects who were still not sure of the required procedure were given the opportunity to be guided individually. The production part of MLK was administered separated from the multiple-choice part to prevent carrying test-effect over the other part. This test stimulated the use of rule, was un-pressured, focused attention on form, and encouraged the use of MLK.

The MLK test was not designed to elicit the L2 learners feel for what was grammatical, it required the L2 learners to process language, and encouraged the use of metalinguistic knowledge. The results of studies indicate (Dekeyser, 1995; Ellis \& Han, 1998; Robinson, 1996) that the amount of time given to the subjects influences the type of knowledge they draw on. When learners are permitted to make judgments in their own time, they can have access to whatever explicit knowledge of the L2 structure they internalized. The tests were administered during the L2 learners' regular class time. All groups were tested under the supervision of the researcher. In each class, the tests were in familiar paper-and-pencil format. The L2 learners were under no time pressure.

\section{Results}

The data are analyzed by making two comparisons: (a) the MLK scores and increased proficiency, and (b) MLK scores of all of the participants in both majors.

\subsection{Comparison of MLK test scores and language proficiency scores}

Table 1 shows the means and standard deviations of the participants' proficiency (TOEFL) scores:

\section{Table 1}

Descriptive Statistics for the Students' TOEFL Scores

\begin{tabular}{lllll}
\hline Students' grade & TOEFL Scores & N & Mean & SD \\
\hline Freshmen & TOEFL Reading & 96 & 22.30 & 4.36 \\
& TOEFL GJ & 99 & 15.05 & 2.83 \\
& TOEFL Multiple-Choice & 98 & 31.50 & 2.03 \\
& TOEFL Total & 97 & 22.95 & 1.74 \\
\hline Sophomores & TOEFL Reading & 97 & 66.09 & 3.89 \\
& TOEFL GJ & 95 & 59.79 & 2.28 \\
& TOEFL Multiple-Choice & 98 & 72.02 & 1.12 \\
& TOEFL Total & 96 & 65.96 & 1.25 \\
\hline Juniors & TOEFL Reading & 99 & 42.02 & 4.45 \\
& TOEFL GJ & 94 & 37.13 & 3.10 \\
& TOEFL Multiple-Choice & 95 & 51.09 & 2.28 \\
& TOEFL Total & 96 & 43.41 & 1.27 \\
\hline Seniors & TOEFL Reading & 93 & 85.50 & 3.00 \\
& TOEFL GJ & 98 & 89.89 & 1.92 \\
& TOEFL Multiple-Choice & 95 & 92.39 & 1.17 \\
& TOEFL Total & 95 & 89.26 & 1.28 \\
\hline
\end{tabular}


The descriptive statistics for the participants' performance on sub-sections of the metalanguage test by increased proficiency are shown in Table 2. The table shows that the participants' performance improved but not significantly over the period of their undergraduate study and with generally small variations. The table also demonstrates that the Metalanguage test proved harder for the freshmen participants than for the other groups of participants, but not significantly. Another noticeable and significant difference between different grades of the participants lies in freshmen performance on the production part of the test. Indeed, this is not a surprising result since the freshmen are expected to be at a lower level of L2 proficiency and production processes cause difficulty for them.

Table 2

Descriptive Statistics of MLK Test by Proficiency

\begin{tabular}{|c|c|c|c|c|c|}
\hline & Parts of the MLK Test & $\mathrm{N}$ & Mean & SD & Variance \\
\hline \multirow[t]{6}{*}{ Freshmen } & Production Part & 65 & 10.40 & 4.25 & 18.06 \\
\hline & Underline Part & 65 & 6.88 & 2.18 & 4.74 \\
\hline & Multiple Choice Part & 65 & 4.94 & 1.75 & 3.06 \\
\hline & Language Analytic Part & 41 & 2.51 & 1.00 & 1.01 \\
\hline & Year & 65 & 1.00 & .00 & .00 \\
\hline & Valid N & 41 & & & \\
\hline \multirow[t]{6}{*}{ Sophomores } & Production Part & 43 & 9.42 & 3.74 & 13.96 \\
\hline & Underline Part & 43 & 7.21 & 1.66 & 2.74 \\
\hline & Multiple Choice Part & 39 & 6.08 & 1.68 & 2.81 \\
\hline & Language Analytic Part & 31 & 3.00 & 1.00 & 1.00 \\
\hline & Year & 44 & 2.00 & .00 & .00 \\
\hline & Valid N & 31 & & & \\
\hline \multirow[t]{6}{*}{ Juniors } & Production Part & 46 & 11.43 & 4.17 & 17.41 \\
\hline & Underline Part & 44 & 7.25 & 1.66 & 2.75 \\
\hline & Multiple Choice Part & 46 & 6.04 & 1.28 & 1.64 \\
\hline & Language Analytic Part & 46 & 3.28 & .93 & .87 \\
\hline & Year & 46 & 3.00 & .00 & .00 \\
\hline & Valid N & 44 & & & \\
\hline \multirow[t]{6}{*}{ Seniors } & Production Part & 42 & 12.55 & 4.89 & 23.91 \\
\hline & Underline Part & 42 & 7.43 & 2.26 & 5.13 \\
\hline & Multiple Choice Part & 42 & 6.26 & 1.25 & 1.56 \\
\hline & Language Analytic Part & 42 & 3.59 & 1.19 & 1.42 \\
\hline & Year & 42 & 4.00 & .00 & .00 \\
\hline & Valid N & 42 & & & \\
\hline
\end{tabular}

\subsection{Comparison of the MLK test scores and the participants' scores by major}

The descriptive statistics for the sub-sections of the metalanguage test by major are shown in Table 3 . The table shows, overall, the metalanguage test was more challenging for the Literature participants than the Translation ones, with the Language Analytic Section proving significantly the most difficult part ( $\mathrm{M}=3.35$ for Translation learners, $\mathrm{M}=2.87$ for Literature ones).

Table 3

Descriptive Statistics of MLK Test by major

\begin{tabular}{lllllll}
\hline Major & Parts of the MLK & $\mathrm{N}$ & Minimum & Maximum & Mean & SD \\
\hline Translation & Multiple Choice & 96 & 2.00 & 9.00 & 5.78 & 1.61 \\
& Paragraphs & 80 & 1.00 & 6.00 & 3.35 & 1.15 \\
& Production & 98 & 3.00 & 23.00 & 11.22 & 4.34 \\
& Underline & 97 & 1.00 & 11.00 & 7.17 & 2.03 \\
& Valid N (list wise) & 79 & & & & \\
\hline
\end{tabular}


The impact of translation on L2 learners' metalinguistic competence

Table 3 ... continued

\begin{tabular}{lllllll}
\hline Major & Parts of the MLK & N & Minimum & Maximum & Mean & SD \\
\hline Literature & Multiple Choice & 96 & 2.00 & 9.00 & 5.66 & 1.61 \\
& Paragraphs & 80 & 1.00 & 5.00 & 2.87 & .99 \\
& Production & 98 & 2.00 & 25.00 & 10.55 & 4.40 \\
& Underline & 97 & 1.00 & 11.00 & 7.13 & 1.93 \\
& Valid N (list wise) & 79 & & & & \\
\hline
\end{tabular}

To investigate the intercept effects of proficiency and major on different Parts of the MLK test MANOVA analysis was employed, as illustrated in table 4.

\section{Table 4}

Tests of Between-Subjects Effects

\begin{tabular}{|c|c|c|c|c|c|c|}
\hline Source & $\begin{array}{c}\text { Dependent } \\
\text { Variable }\end{array}$ & $\begin{array}{c}\text { Type III Sum of } \\
\text { Squares }\end{array}$ & df & Mean Square & $\mathrm{F}$ & Sig. \\
\hline \multirow[t]{4}{*}{ Corrected Model } & Multiple Choice & $18.20(\mathrm{a})$ & 7 & 2.60 & 1.035 & .40 \\
\hline & Production & $206.21(b)$ & 7 & 29.45 & 1.50 & .18 \\
\hline & Underline & $7.77(\mathrm{c})$ & 7 & 1.10 & .268 & .96 \\
\hline & Paragraphs & $43.08(\mathrm{~d})$ & 7 & 6.15 & 6.16 & .00 \\
\hline \multirow[t]{4}{*}{ Intercept } & Multiple Choice & 5365.64 & 1 & 5365.67 & 2135.02 & .00 \\
\hline & Production & 19337.78 & 1 & 19337.77 & 990.53 & .00 \\
\hline & Underline & 7940.25 & 1 & 7940.24 & 1921.16 & .00 \\
\hline & Paragraphs & 1493.74 & 1 & 1493.74 & 1497.33 & .00 \\
\hline \multirow[t]{4}{*}{ Major } & Multiple Choice & .64 & 1 & .64 & .255 & .61 \\
\hline & Production & 25.25 & 1 & 25.25 & 1.29 & .25 \\
\hline & Underline & .10 & 1 & .098 & .024 & .87 \\
\hline & Paragraphs & 8.77 & 1 & 8.76 & 8.78 & .00 \\
\hline \multirow[t]{4}{*}{ Year } & Multiple Choice & 17.18 & 3 & 5.72 & 2.27 & .08 \\
\hline & Production & 169.43 & 3 & 56.47 & 2.89 & .03 \\
\hline & Underline & 7.30 & 3 & 2.43 & .589 & .62 \\
\hline & Paragraphs & 26.91 & 3 & 8.97 & 8.99 & .08 \\
\hline \multirow[t]{4}{*}{ Major * Year } & Multiple Choice & .30 & 3 & .10 & .040 & .98 \\
\hline & Production & 10.22 & 3 & 3.40 & .175 & .91 \\
\hline & Underline & .32 & 3 & .10 & .026 & .99 \\
\hline & Paragraphs & 6.87 & 3 & 2.29 & 2.29 & .08 \\
\hline \multirow[t]{4}{*}{ Error } & Multiple Choice & 376.97 & 150 & 2.51 & & \\
\hline & Production & 2928.39 & 150 & 19.52 & & \\
\hline & Underline & 619.95 & 150 & 4.13 & & \\
\hline & Paragraphs & 149.64 & 150 & .99 & & \\
\hline \multirow[t]{4}{*}{ Total } & Multiple Choice & 5881.00 & 158 & & & \\
\hline & Production & 23278.00 & 158 & & & \\
\hline & Underline & 8738.00 & 158 & & & \\
\hline & Paragraphs & 1731.00 & 158 & & & \\
\hline \multirow[t]{4}{*}{ Corrected Total } & Multiple Choice & 395.17 & 157 & & & \\
\hline & Production & 3134.60 & 157 & & & \\
\hline & Underline & 627.72 & 157 & & & \\
\hline & Paragraphs & 192.71 & 157 & & & \\
\hline
\end{tabular}

To conclude, the correlation between improvements in metalinguistic scores and improvements in proficiency is not significant. The only significant relationship was between the production part and the measure of proficiency. Perhaps, it provides support to prior studies (Alderson et al., 1997; Elder et al., 1999; Elder \& Manwaring, 2004; Green \& Hecht, 1992; Klapper \& Rees, 2003; Renou, 2000; Sorace, 1985) which has shown that language proficiency plays only an insignificant role in metalingual knowledge. With regard to the second research question it is shown that the only variable which showed the strongest significant relationships with translation major grades was language analytic sub-section of MLK test since presumably translation learners are taught to think about how language works pragmatically during their translation courses and this section of MLK 
focused on pragmatic and contextual features as well. However, with regard to the third research question, no statically significant difference were found in the performance of literature and translation participant on the Production, Underline, Multiple Choice, and language analytic Parts of the MLK test.

\section{Discussion}

This research set out to address three inter-related questions concerning whether an intensive exposure on translation was a sufficiently influential intervention to generate an improvement in learners' MLK as compared to a group who did not receive the course. In order to answer second and third research questions, the author analyzed the inter-group data. As it was shown in table 3, translation was not sufficient by itself to induce a significant improvement in learners' MLK when compared to the comparison group. There was, however, evidence of a greater ability of language analytic skill in seniors' translation participants (figure 1).

Within language analysis part of MLK the recognition of a linguistic unit in relation to other linguistic units and comparison across sentences was required. The factor contributed to the Translation participants' greater use of language analytic competence is that translation participants had to compare two languages and, therefore, forced to sort out the semantic, syntactic, and orthographic differences that exist between the two languages on a regular basis. The results are in accordance with the argument stated by Kessler and Quinn (1987) that regular exposure to two languages and their linguistic codes can bring about a higher cognitive competence. The results are also consistent with the hypothesis that language knowledge comes up from language competence rather than the other way round (Roehr, 2007). Regarding the fact that language analytic section examined the capability to identify how words function grammatically in sentences and the ability to infer grammatical rules from language examples, seniors' translation participants had taken greater competence of grammatical functioning of the words in texts which has been achieved through processes of analysis and reflection of underlying structures of language while translating, analyzing and joining of patterns, paying attention to the relationship between form and meaning, controlling their linguistic knowledge, and using sufficient analyzed knowledge and time at the time of translation (Cummins, 1984; Edelsky, 1986; Kaur, 2005; Sager, 1994; Ringbom, 1987). All of these processes are enough to consider it as a conscious-raising task designed to develop learners' awareness of how specific linguistic features work (Fotos \& Ellis, 1991; Rutherford, 1987).

Generally, literature participants' relative poorer performance on this part is not attributable, therefore, to deficiency of linguistic competence, as both groups were in the same level of language proficiency, rather to a lower flexibility, analytic orientation, and inferring ability to linguistic input which haven't been required as a field necessity.

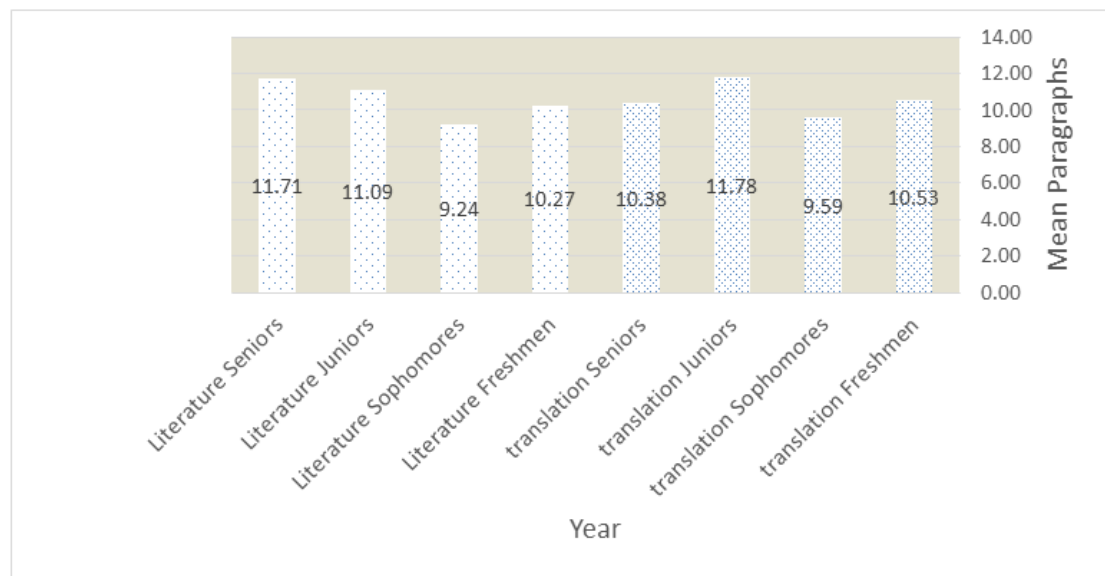

Figure 1: Both majors' performances on the language analytic section

The first research question concerned the effects of language proficiency on participants MLK, as measured in a narrow sense. As we noted in the introduction, dispute exists about the relationship between these two variables (Alderson et al., 1997; Elder et al., 1999; Elder \& Manwaring, 2004; Green \& Hecht, 1992; Klapper \& 
Rees, 2003; Renou, 2000; Sorace, 1985). However, no statistically significant evidence between measures of the proficiency and MLK Test were found as shown in table 2. These results confirm the earlier findings (Alderson et al., 1997; Hulstijn \& Hulstijn, 1984; seliger, 1979) that language proficiency does not impact on MLK.

A key finding was that generally the differences between the groups are non-significant on the Language Analytic, Multiple Choices, and the Underline Part of the test but proficient participants performed significantly better on the Production (correction- explanation) Part of test (figure 2).

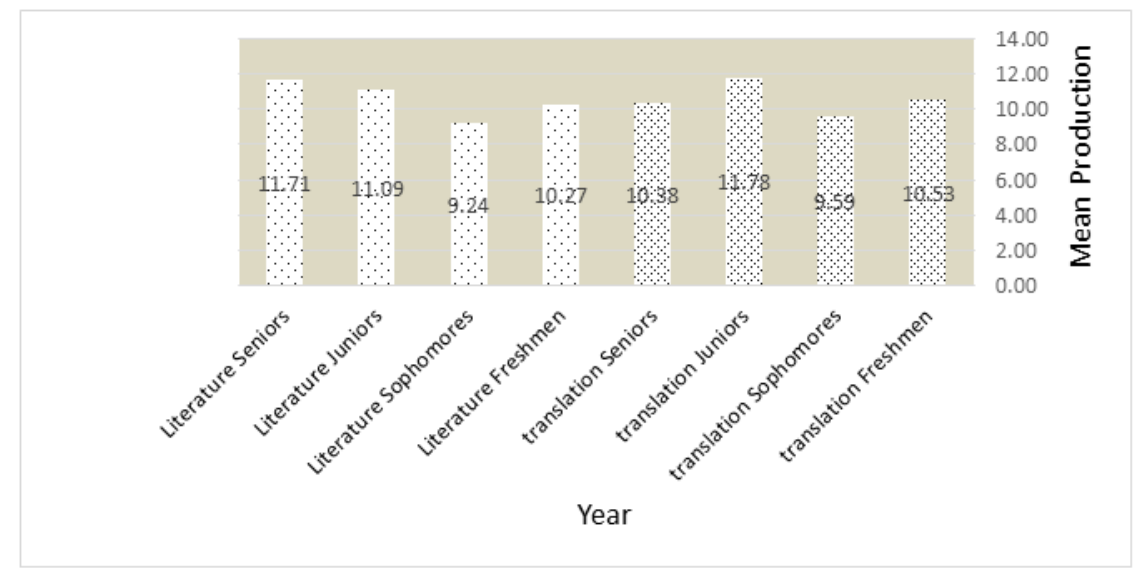

Figure 2: Both Majors' Pertormances on the Production Part

The study believes that the significant performance of proficient participants is related to other factors such as task or item requirements rather than proficiency. Linguistic knowledge manifests itself based on task requirements (Bialystok, 1982). The participants' cognitive processes are totally focused on identifying errors during error identification, while in production tasks the concentration is divided among a number of problems and also simultaneously over the production processes which is challenging for less proficient learners. This statement can justify why less proficient participants performed better on the high structured Multiple Choice Part in comparison to free production description-explanation part, although they possessed similar questions. In other words, different kinds of knowledge are enacted by different types of language use (Bialystok, 1982).

To be more precise, correction-explanation section of the MLK test required participants to correct the ungrammatical parts. Those with different proficiency level drew on different knowledge, freshmen may have relied on the similar kind of knowledge for all questions, and, possibly, this type of knowledge was implicit. The explanation part required learners to explain about the grammatical category in which the error occurred something like "if-then" statements. More proficient participants in both fields used more sophisticated explanation comments. The inferior performance of the freshmen on the explanation part can be attributed to the fact that many of them were just beginning to grapple with the reasoning processes and they were still immature in the production and explanation skills involved in describing some errors occurred and the application of these skills. A larger number of the seniors did not have the problem of applying these skills since they had applied and used them during their undergraduate studies and have the power of increased proficiency. However, Cummins (1978) believes that it would be a mistake to assume that stating of the principle was more indicative of cognitive skills than ability to apply it. These different patterns observed for the performances of the freshmen, sophomores, juniors, and seniors on the description section of the MLK test explains why standard deviation represent a degree of variation in scores on the Production Part. The research findings, then, provide tentative support to studies previously cited (Alderson et. al., 1997; Han \& Ellis, 1998; Seliger, 1979) that MLK does not appear to be related to language proficiency.

\section{Conclusion}

The present atmosphere in FLT doesn't persuade the use of translation as a technique for enhancing L2 MLK competence. The results from this study do not support such a practice, either. On the contrary, it provides 
evidence that receiving translation texts does not have any impact on developing metacognitive abilities. Translation courses were not sufficient as an independent variable to cause the intended change in the Translation participants' interlanguage.

When considering the merits of the results, however, it is worth bearing in mind that the findings were gathered just from a certain subpopulation of L2 participants, that is, educated university-level language learners with considerable exposure to form-focused instruction. Therefore, the current findings may not be generalizable beyond such learners. Besides, the validity of the findings rests heavily on the test used to measure MLK. Because no other tools existed at the time of the study, the researcher devised the test. The test was piloted and psychometrics evidence for the content and construct validity of the MLK test used has been presented; nevertheless, the main findings must be considered cautiously.

There are a number of implications despite the study limitations. The inclusion of translation where the initial course objective is learners' development of the four language skills may seem inadequate, however, it might prove useful for courses which emphasize what we might call an awareness of the structural functioning of a language patterns. Moreover, most learners regard language as a means of communication and a referential system, but not as an object of reflection, or a string of elements that can be parsed into structural units, or even judging the form of language as distinct from its content. Such findings can aware them through creating a mindset to regard language as an object of consideration and analysis, and as a technique to enhance their competence.

No attempt was made to obtain retrospective information relating to the strategies the participants employed when completing the MLK test. Although the focus of the study was on certain grammatical features and hopefully it is applicable to other grammatical structures, this remains to be shown. Considerably, more research is needed to elucidate the nature of learners' metalinguistic awareness and the development of an analytic orientation to language. A larger-scale study which makes use of a full range of measurement tests of L2 metalinguistic knowledge and language-analytic ability will shed more light on the issue. Nevertheless, further work on developing tests of these two knowledge types is still waiting to be addressed to probe in greater depth the claims that have been put forward here.

\section{References}

Alderson, J. C., Clapham, C., \& Steel, D. (1997). Metalinguistic knowledge, language aptitude and language proficiency. Language Teaching Research, 1, 93-121. https://doi.org/10.1177/136216889700100202

Anderson, J. R. (1996). The architecture of cognition. Mahwah, NJ: Erlbaum.

Anderson, J. R. (2005). Cognitive psychology and its implications (6th ed.). New York, NY: Worth Publishers.

Andrew, S. (1999): Why do L2 teachers need to know about language? Teacher metalinguistic awareness and input for learning. Language and Education, 13(3), 161-177. https://doi.org/10.1080/09500789908666766

Bachman, L. F., \& Palmer, A. S. (1996). Language testing in practice: Designing and developing useful language tests. Oxford: Oxford University Press.

Baynham, M. (1983). Mother tongue materials and second language literacy. ELT Journal, 37(4), 312-318. https://doi.org/10.1093/elt/37.4.312

Bialystok, E. (1982). On the relationship between knowing and using linguistic forms. Applied Linguistics, 3, 181-206. https://doi.org/10.1093/applin/3.3.181

Bialystok, E. (1987). Influences of bilingualism on metalinguistic development. Second Language Research, 3(2), 154-66. https://doi.org/10.1177/026765838700300205

Bialystok, E., \& Ryan, E. (1985). A metacognitive framework for the development of first and second language skills. In D. Forrest-Pressely, G. Mackinnon \& T. Waller (Eds.), Metacognition, cognition and human performance (pp. 207-252). Orlando, FL: Academic press.

Chamot, A. U., \& Kupper, L. (1989). Learning strategies in foreign language instruction. Foreign Language 
The impact of translation on L2 learners' metalinguistic competence

Annals, 22, 13-24. https://doi.org/10.1111/j.1944-9720.1989.tb03138.x

Chamot, A. U., O’Malley, J. M., Kupper, L., \& Impink - Hernandez, M. V. (1987). A study of learning strategies in foreign language instruction: First year report. Rosslyn, VA: Interstate Research Associates.

Clark, E. (1978). Awareness of language: Some evidence of what children say and do. In Sinclair et al. (Eds.), The child's conception of languages. Berlin: Springer virlag.

Cohen, A. D., \& Brooks-Carson, A. (2001). Research on direct versus translated writing: Students' strategies and their results. The Mother Language Journal, 85(2), 169-188. https://doi.org/10.1111/0026-7902.00103

Dakowska, M. (1993). Issues in the cognitive modeling of second language acquisition. Kwartalnik Iveofilobgkzny, 39(3), 199-211.

Durrell, M. (1992). Using German: A guide to contemporary usage. Cambridge: Cambridge University Press.

Durrell, M. (1996). Hammer's German grammar and usage (3rd ed.). London: Arnold.

Elder, C., \& Manwaring, D. (2004). The relationship between metalinguistic knowledge and learning outcomes among undergraduate students of Chinese. Language Awareness, 13(3), 145-162. https://doi.org/10.1080/09658410408667092

Elder, C., Warren, J., Hajek, J., Manwaring, D., \& Davies, A. (1999). Metalinguistic knowledge: How important is it in studying a language at university? Australian Review of Applied Linguistics, 22(1), 81-95. https://doi.org/10.1075/aral.22.1.04eld

Ellis, N. C. (2005). At the interface: Dynamic interactions of explicit and implicit language knowledge. Studies in Second Language Acquisition, 27(2), 305-352. https://doi.org/10.1017/S027226310505014X

Ellis, N. C., \& Larsen-Freeman, D. (2006). Language emergence: Implications for applied linguistics. Applied Linguistics, 27(4), 558-589. https://doi.org/10.1093/applin/aml028

Ellis, R. (1985). Understanding second language acquisition. Oxford: Oxford University Press.

Ellis, R. (1986). Understanding second language acquisition. Oxford: Oxford university press.

Ellis, R. (2006). Modeling learning difficulty and second language proficiency: The differential contributions of implicit and explicit knowledge. Applied Linguistics, 27(3), 431-463. https://doi.org/10.1093/applin/aml022

Fotos, S., \& Ellis, R. (1991). Communicating about grammar: A task-based approach. TESOL Quarterly, 25, 605-628. https://doi.org/10.2307/3587079

Green, P. S., \& Hecht, K. (1992). Implicit and explicit grammar: An empirical study. Applied Linguistics, 13(2), 168-184. https://doi.org/10.1093/applin/13.2.168

Han, Y. \& Ellis, R. (1998). Implicit knowledge, explicit knowledge, and general language proficiency. Language Teaching Research, 2, 1-23. https://doi.org/10.1191/136216898672061211

Hulstijn, J., \& Hulstijn, W. (1984). Grammatical errors as a function of processing constraints and explicit knowledge. Language Learning, 34, 23-43. https://doi.org/10.1111/j.1467-1770.1984.tb00994.x

James, C., \& Garrett, P. (1992). The scope of awareness. In C. James \& P. Garrett (Eds.): Language awareness in the classroom (pp. 3-20). London: Longman.

Karmiloff-Smith, A., Grant, J., Sims, K., Jones, M. C., \& Cuckle, P. (1996). Rethinking metalinguistic awareness: representing and accessing knowledge about what counts as a "word". Cognition, 58(2), 197-219. https://doi.org/10.1016/0010-0277(95)00680-X

Kaur, K. (2005). Parallelism between language learning and translating. Translation Journal. Retrieved from http://translationjournal.net/journal/33edu.htm

Kern, R. (1994). The role of mental translation in second language reading. Studies in Second Language Acquisition, 16, 441-461. https://doi.org/10.1017/S0272263100013450

Kessler, C., \& Quinn, M. E. (1987). ESL and science learning. In J. Crandall (Eds.), ESL through content-area instruction (pp. 55-87). Englewood Cliffs, NJ: Prentice Hall Regents.

Klapper, J., \& Rees, J. (2003). Reviewing the case for explicit grammar instruction in the university foreign language learning context. Language Teaching Research, 7(3), 285-314. https://doi.org/10.1191/13621688031r128oa

Kobayashi, H., \& Rinnert, C. (1992). Effects of first language on second language writing: Translation versus direct composition. Language Learning, 42(2), 183-215. 
https://doi.org/10.1111/j.1467-1770.1992.tb00707.x

Krashen, S. (1984). Writing: Research, theory, and applications. Oxford: Pergamon.

Lazo, M., Pumfrey, D., \& Peer, I. (1997). Metalinguistic awareness, reading and spelling: Roots and branches of literacy. Journal of Research in Reading, 20(2), 85-104. https://doi.org/10.1111/1467-9817.00023

Macaro, E. (2006). Strategies for language learning and for language use: Revising the theoretical framework. Modern Language Journal, 90(3), 320-337. https://doi.org/10.1111/j.1540-4781.2006.00425.x

Marti Viano, M. D., \& Orquin, V. (1982). Identifying our students' strategy for learning English as a foreign language. Modern English Teacher, 9(4), 38-41.

McDonough, S. (2002). Applied linguistics in language education. London: Arnold.

Nagata, H., Aline, D., \& Ellis, R. (1999). Modified input, language aptitude and the acquisition of word meanings. In R. Ellis (Ed.), Learning a second language through interaction (pp. 133-149). Amsterdam: John Benjamins. https://doi.org/10.1075/sibil.17.09nag

Naiman, N., Fröhlich, M., Stern, H. H., \& Todesco, A. (1978). The good language learner (Research in Education Series No. 7). Toronto, Canada: Ontario Institute for Studies in Education.

Newmark, P. (1991). About translation. Clevedon, UK: Multilingual Matters.

Nunnan, D. (1999). Second language teaching and learning. Boston: Heinle \& Heinle Publishers.

O’Malley, J. M., \& Chamot, A. U. (1990). Learning strategies in second language acquisition. Cambridge: Cambridge University Press. https://doi.org/10.1017/CBO9781139524490

O’Malley, J. M., Chamot, A. U., Kupper, G. L., \& Russo, R. P. (1985a). Learning strategies used by beginning and intermediate ESL students. Language Learning, 35, 21-46. https://doi.org/10.1111/j.1467-1770.1985.tb01013.x

O’Malley, J. M., Chamot, A. U., Kupper, G. L., \& Russo, R. P. (1985b). Learning strategy applications with students of English as a second language. TESOL Quarterly, 19, 557-584. https://doi.org/10.2307/3586278

Omura, Y. (1996). Role of translation in second language acquisition: Do learners automatically translate? (Unpublished doctoral thesis). University of Texas at Austin.

Oxford, R. L. (1990). Language learning strategies—what every teacher should know. New York: Newbury House Publishers.

Paradis, M. (2004). A neurolinguistic theory of bilingualism. Amsterdam: John Benjamins. https://doi.org/10.1075/sibil.18

Perkins, C. (1985). Sensitizing advanced learners to problems of L1-L2 translation. In C. Tiford \& A. E. Hiehe (Eds.), Translation in foreign language teaching and testing (pp. 51-72). Tubingen: Narr

Petrocchi, V. (2003). Translation as an aid in teaching English as a second language. Translation Journal. Retrieved from http://www.bokorlang.com/journal/38teaching.htm

Politzer, R. L. (1983). An exploratory study of self-reported language learning behaviors and their relationship to achievement. Studies in second language acquisition, 6(1), 54-68. https://doi.org/10.1017/S0272263100000292

Prince, P. (1996). Second language vocabulary learning: The role of context versus translation as a function of proficiency. The Modern Language Journal, 80, 478-493. https://doi.org/10.1111/j.1540-4781.1996.tb05468.x

Ranta, L. (2002). The role of learners' language analytic ability in the communicative classroom. In P. Robinson (Ed.), Individual differences and instructed language learning (pp. 159-80). Amsterdam: John Benjamins. https://doi.org/10.1075/1llt.2.11ran

Roehr, K. (2007). Metalinguistic knowledge and language ability in university level L2 learners. Applied Linguistics, 29(2), 173-199. https://doi.org/10.1093/applin/amm037

Ruan, J. (2004). Bilingual Chinese-English first-graders developing metacognition about writing. Literacy, 38(2), 106-112. https://doi.org/10.1111/j.0034-0472.2004.03802007.x

Rutherford, W. E. (1987). Second language grammar: Learning and teaching. London: Longman.

Sinclair, A. (1986). Metalinguistic knowledge and language development. In I. Kurcz, G. W. Shugar, \& J.H. Danks (Eds.), Knowledge and language (pp. 609-627). North-Holland: Elsevier Science Publishers. 
https://doi.org/10.1016/S0166-4115(09)60155-2

Skehan, P. (1986). Cluster analysis and the identification of learner types. In V. Cook (Ed.), Experimental approaches to second language learning (pp. 81-94). Oxford: Pergamon.

Skehan, P. (1989). Individual differences in second- language learning. London: Arnold.

Sorace, A. (1985). Metalinguistic knowledge and language use in acquisition-poor environments. Applied Linguistics, 6(3), 239-254. https://doi.org/10.1093/applin/6.3.239

Swain, M. (1985). Communicative competence: Some roles of comprehensible input and comprehensible output in its development. In S. M. Gass \& C. G. Madden (Eds.), Input in second language acquisition (pp. 235-254). Rowley, MA: Newbury.

Swain, M. (1988). Manipulating and complementing content teaching to maximize second language learning. TESL Canada Journal, 6, 68-83. https://doi.org/10.18806/tesl.v6i1.542

Swan, M. (1994). Design criteria for pedagogic language rules. In M. Bygate, A. Tonkyn \& E. Williams (Eds.), Grammar and the language teacher (pp. 45-55). New York, NY: Prentice Hall,

Tiford, C. (1985). Translation a post communicative activity for advanced learners. In C. Titford \& A. E. Hiehe (Eds.), Translation in foreign language teaching and testing (pp. 73-86). Tubingen: Narr.

Tunmer, W. (1997). Metalinguistic skill in reading development. In V. Edward \& D. Corson (Eds.), Encyclopedia of language and education: Literacy, 2 (pp. 27-36). Dordrecht: Kluwer Academic Publishers. https://doi.org/10.1007/978-94-011-4540-4_4

Westney, P. (1994). Rules and pedagogical grammar. In T. Odlin (Ed.), Perspectives on Pedagogical Grammar (pp. 72-96). Cambridge: Cambridge University Press. https://doi.org/10.1017/CBO9781139524605.006

Wills, W. (1996). Knowledge and skills in translator behavior. Amsterdam: John Benjamins. https://doi.org/10.1075/btl.15 
Parinaz, K., \& Biria, R. 